\title{
ACCELERATING FLOW OF THE BRUNT ICE SHELF, ANTARCTICA
}

\author{
By D. A. Simmons and J. R. Rouse
}

(British Antarctic Survey, Natural Environment Research Council, High Cross, Madingley Road, Cambridge CB3 0ET, England)

Abstract. Position fixes made at the British Antarctic Survey station, Halley, on the Brunt Ice Shelf are considered for the period 1968-82. These show an initial westward velocity of approximately $400 \mathrm{~m} \mathrm{a}^{-1}$ rising to over $700 \mathrm{~m} \mathrm{a}^{-1}$ by the end of the period. The data are well fitted by two straight lines. The first for 1968-71 has a slope $430 \mathrm{~m} \mathrm{a}^{-1}$ in agreement with that found by Thomas (1973) for the period up to 1968. The second for 1972-83 has a slope $740 \mathrm{~m} \mathrm{a}^{-1}$, a large increase sustained for up to 10 years.

RésumÉ. Accéleration de l'écoulement du Brunt Ice Shelf, Antarctique. Des déterminations de points effectuées à la station Halley, British Antarctic Survey, sur le Brunt Ice Shelf sont examinées pour la période de 1968 à 1982. Elles révèlent une vitesse dirigée à l'ouest d'environ $400 \mathrm{~m} \mathrm{a}^{-1}$ croissant à plus de $700 \mathrm{~m} \mathrm{a}^{-1}$ vers la fin de la période. Les données sont bien representées par deux lignes droites. La première, de 1968 à 1971, a une pente de $430 \mathrm{~m} \mathrm{a}^{-1}$, conformément à ce qu'a trouvé Thomas (1973) pour la

\section{INTRODUCTION}

The Brunt Ice Shelf lies on the eastern coast of the Weddell Sea and has been the site of intermittent glaciological investigations since 1956, when the Royal Society established a base there for the International Geophysical Year (I.G.Y.). The British Antarctic Survey station, Halley, lies on the southwestern corner of the ice shelf at lat. $75^{\circ} 31^{\prime} \mathrm{S}$., long. $27^{\circ} 00^{\prime} \mathrm{W}$. (in 1983). Figure 1 is a map of the Brunt Ice Shelf (from Thomas, 1973).

The history and morphology of the area up to 1968 have been described by Limbert (1963, 1964), Barclay (1964), Ardus (1965[a],[b]), and Thomas (1973). Investigations during this period showed that the ice near Halley was moving approximately due west at about $400 \mathrm{~m}$ per year and that this rate had been constant to within $\pm 25 \mathrm{~m}$ per year since the establishment of the station. Since 1956, the station has occupied buildings on two distinct sites, the major site change being in 1967-68, when the I.G.Y. site was abandoned and a new site $3 \mathrm{~km}$ further east was chosen. During 1983-84 the station position changed again when new buildings became operational.

During the period of occupation, the position of the station has been regularly determined in a number of different ways. The data for the period up to 1968 have been discussed (Thomas, 1973) and cover the original (I.G.Y.) site. The data presented here cover the period 1968-82, after the first site change. They were not collected specifically for glaciological purposes and, as a result, were not obtained at a single geographical position throughout the time series. Nevertheless, they show that there has been a marked increase in velocity since 1956-68.

\section{POSITION}

Three distinct methods of position fixing were used; astronomical fixes, satellite navigation fixes, and the magnetic survey of an area of high geomagnetic field gradient. Local surveys enabled the results of these three methods to be referred to a single point on the site. période antéreiure à 1968. La seconde, de 1972 à 1982, a une pente de $740 \mathrm{~m} \mathrm{a}^{-1}$, c'est-à-dire une importante augmentation continue pendant ces dix années.

Zusammenfassung. Beschleunigtes Fliessen des Brunt Ice Shelf, Antarktika. Lagebestimmungen auf dem Brunt Ice Shelf bei der British Antarctic Survey Station Halley während der Periode 1968-82 werden untersucht. Sie ergeben eine ursprüngliche Bewegung nach Westen von etwa $400 \mathrm{~m}$ pro $\mathrm{Jahr}$, die am Ende der Periode auf über $700 \mathrm{~m}$ pro Jahr anstieg. Diese Daten lassen sich durch zwei gerade Linien gut darstellen. Die erste für 1968-71 hat eine Neigung von $430 \mathrm{~m}$ pro Jahr in Übereinstimmung mit dem von Thomas (1973) gefundenen Wert für die Perode bis 1968; die zweite für 1972-82 hat eine Neigung von $740 \mathrm{~m}$ pro Jahr, also eine starke Zunahme, die über 10 Jahre lang anhielt.

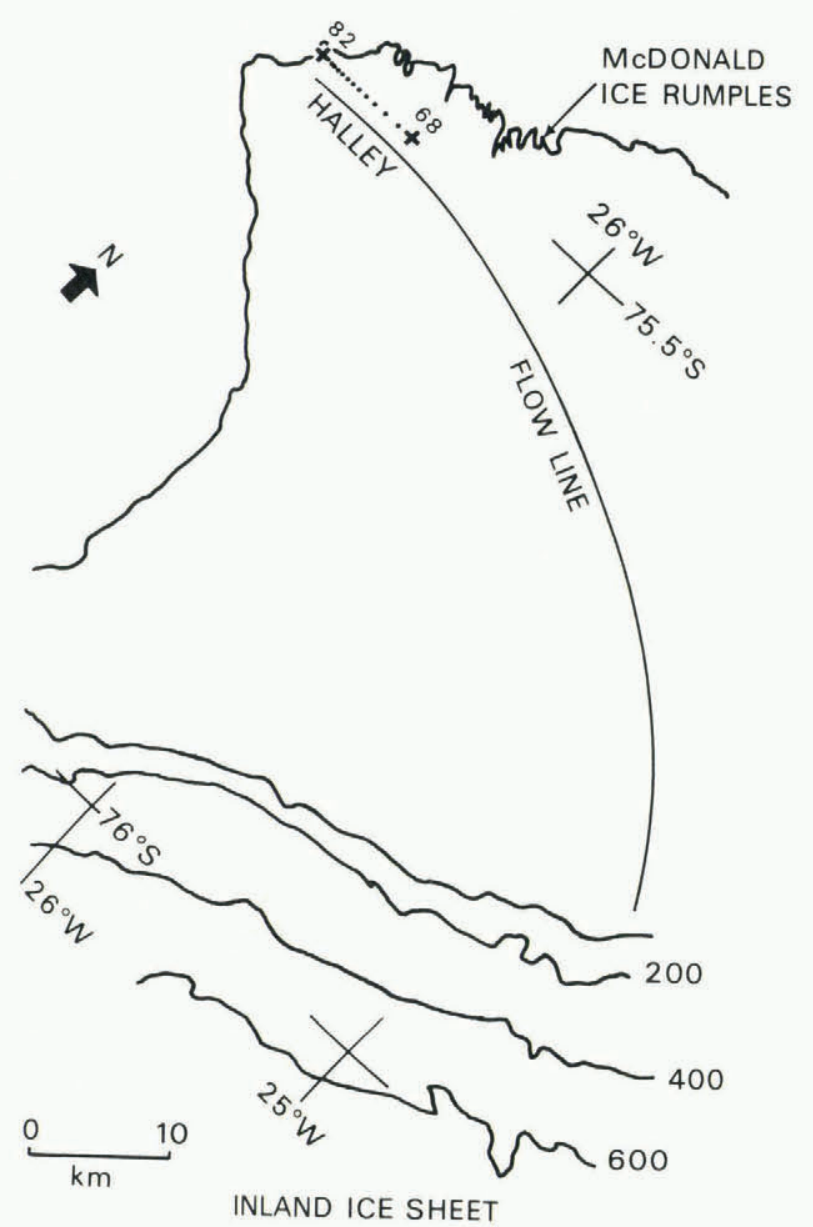

Fig. 1. Brunt Ice Shelf, 1967 (from Thomas, 1973). 


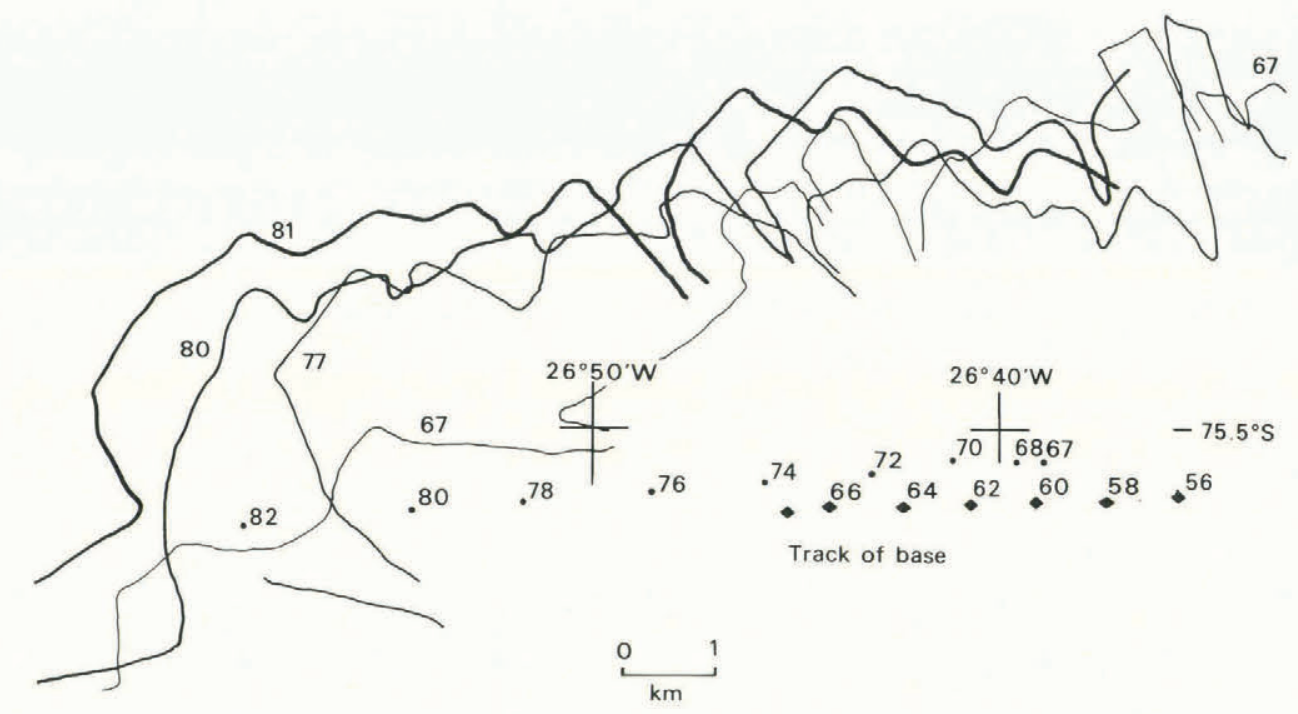

Fig. 2. Position of ice front in 1967, 1977, 1980, and 1981, showing successive positions of the station, 1956-82. Fig. 3. Latitude of Halley, 1968-82.

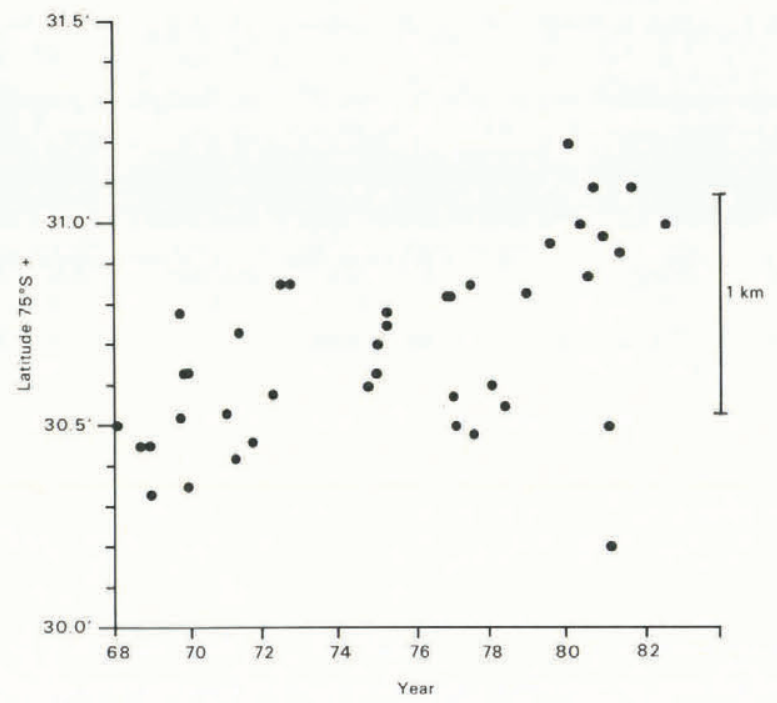

Fig. 3. Latitude of Halley, 1968-82.

Successive positions of the station are shown on the map in Figure 2, and plotted against time in Figures 3 and 4 . Figure 2 also shows the position of the ice front in 1967, 1977, 1980, and 1981. The position of the ice front has remained relatively constant, although the rate of ice flow has increased, possibly supporting the suggestion that ice calving in this area is controlled by sea-bed topography.

Figure 3 gives the results of latitude determinations. These show a southerly movement of up to $100 \mathrm{~m} \mathrm{a}^{-1}$ almost masked by the large scatter. This southerly movement will not be considered further, the subsequent analysis being restricted to the larger westerly movement.

Figure 4 shows the longitude converted to metres west of an arbitary fixed point. The total movement

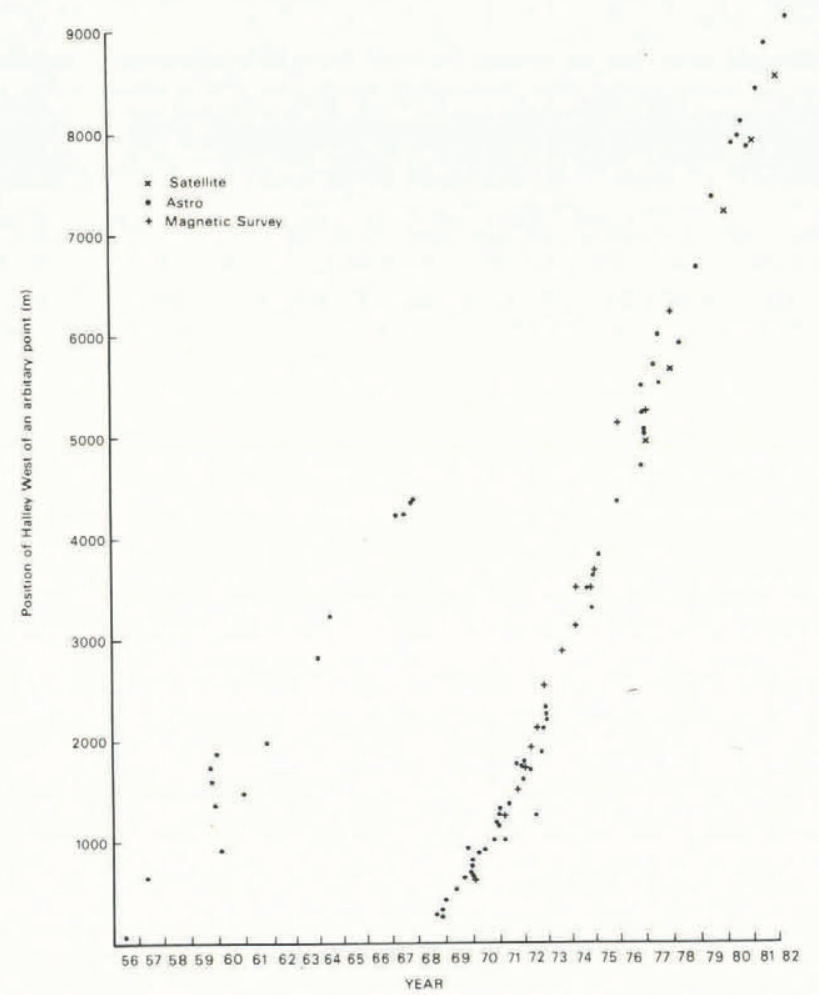

Fig. 4. Position of Halley west of an arbitary point, 1956-82 (note change of site 1967-68).

between 1968 and 1982 was about $9 \mathrm{~km}$ and the associated increase in velocity due to ice-shelf spreading is expected to be less than $20 \mathrm{~m} \mathrm{a}^{-1}$ (Thomas, 1973). It is clear that the observed increase in velocity during this period is much larger than can be explained by movement along the flow line. 


\section{VELOCITY}

The position data (Fig. 4) may be described by two intersecting linear regressions (Table I). The first line, for the period 1968-71, gives a velocity of $431 \pm 22 \mathrm{~m} \mathrm{a}^{-1}$, agreeing with the value $400 \pm$ $20 \mathrm{~m} \mathrm{a}^{-1}$ found by Thomas for the period up to 1968 .

TABLE I. LINEAR FITS TO HALLEY POSITION 1968-71 AND 1972-82

\section{$1968-1971.99 \quad 1972.03-1982$}

$\begin{array}{lrr}\text { Velocity by regression } & 431 \mathrm{~m} \mathrm{a}^{-1} & 740 \mathrm{~m} \mathrm{a}^{-1} \\ \begin{array}{l}\text { Standard error of velocity } \\ \text { estimate }\end{array} & 22 \mathrm{~m} \mathrm{a}^{-1} & 9 \mathrm{~m} \mathrm{a}^{-1} \\ \begin{array}{l}\text { Standard error of position } \\ \text { estimate }\end{array} & 116 \mathrm{~m} & 176 \mathrm{~m}\end{array}$

The second line, for the period 1972-82, gives a value $740 \pm 9 \mathrm{~m} \mathrm{a}^{-1}$ and the two lines intersect in late 1971. Although the slopes are influenced by the exact range of points chosen for each group, these differences are of the same order of magnitude as the error estimates.

The accuracy of single-position fixes varies according to method and, in the case of star shots, from one set of sights to another; the errors may be as large as $\pm 200 \mathrm{~m}$. This agrees well with the standard errors of the position estimates obtained by regression (Table I). The standard error of velocity estimates is of the same order as that given by Thomas (1973) $\left( \pm 25 \mathrm{~m} \mathrm{a}^{-1}\right)$.

The data were also fitted to a smooth curve by a polynomial. This did not, however, give any significant improvement to the fit; the standard error was $\pm 150 \mathrm{~m}$ for the differences between measured and fitted positions.

\section{AZIMUTH}

The principal reason for making the astronomical observations was to obtain the azimuth of a mark, also

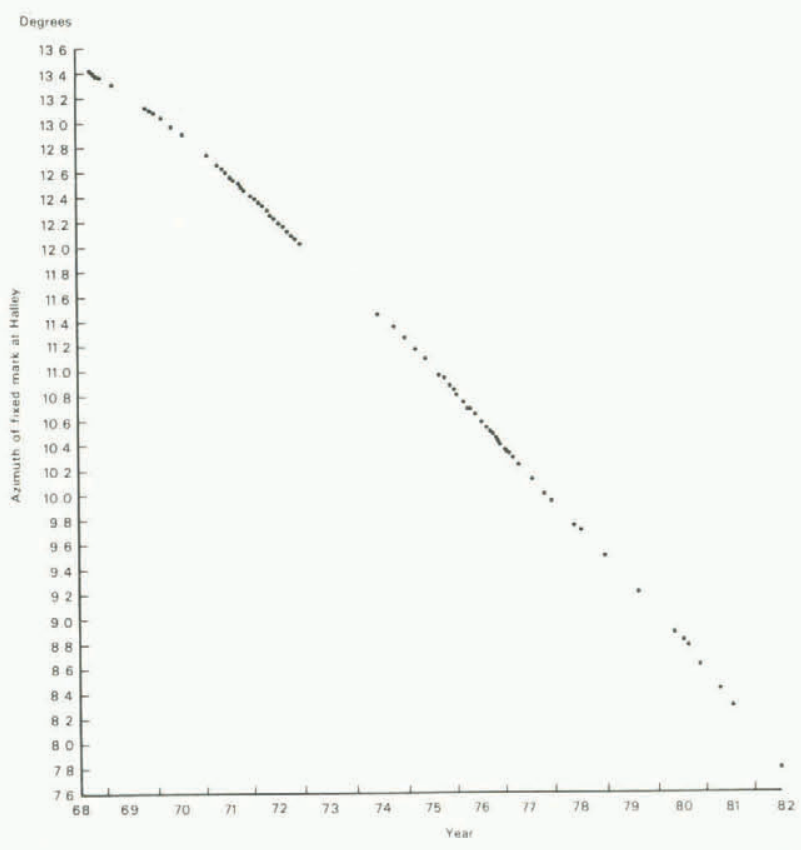

Fig. 5. Azimuth of a fixed mark, 1968-82.

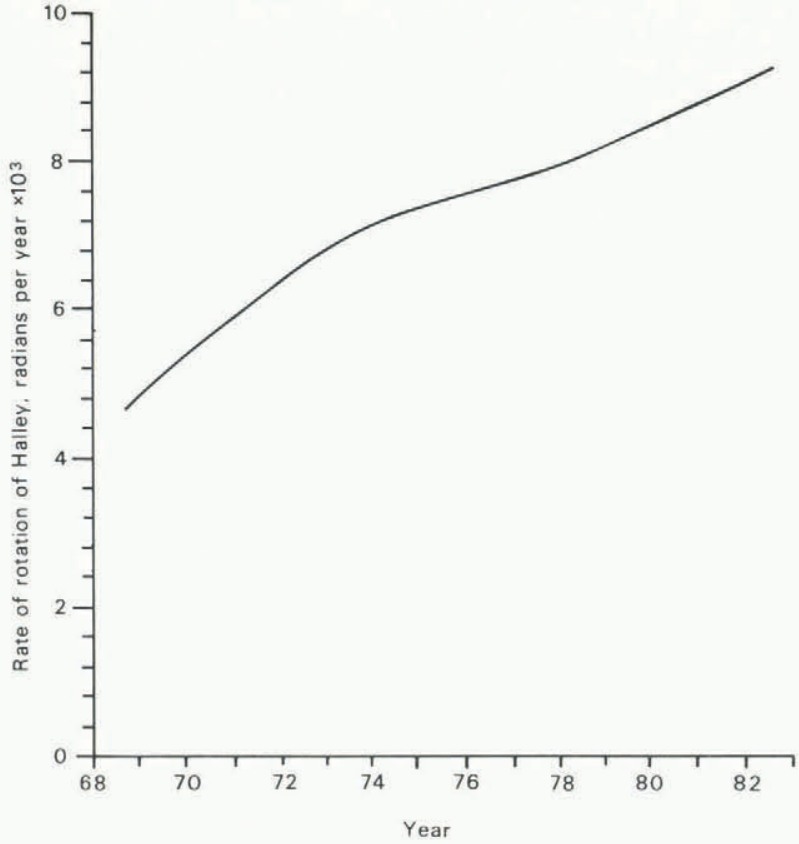

Fig. 6. Rate of rotation of ice shelf at Halley, 1968-82.

on the ice shelf, for use in the programme of geomagnetic observations. These azimuths show the rota$t i o n$ of the ice shelf and are plotted against time in Figure 5. A smooth curve was drawn through these points and the rate of change of azimuth calculated. This rate of change, or rotation, is plotted against time in Figure 6.

\section{DISCUSSION}

The velocity of the ice shelf is governed by both the rate at which the ice flows into the shelf from the plateau and the rate at which the shelf spreads under its own weight. The spreading velocity of the shelf is governed principally by ice-shelf thickness and temperature, and by the restraint caused by locally grounded areas. The motion of the ice shelf in the vicinity of Halley is strongly influenced by the grounded ice at the McDonald Ice Rumples. It is significant that considerable calving occurred in this area in September 1971, at about the time given by the intersection of the two straight lines describing the position data.

If we consider the velocity to be primarily time dependent and assume that the ice shelf is moving as a solid body and rotating about a grounded point, then we can calculate the distance $r$ to the centre of rotation from the linear velocity $v$ and rate of rotation $w$, by $v=\omega r$. This gives a centre of rotation from $85-100 \mathrm{~km}$ south of the station, well inland from the grounding line, which, to the south, is about $65 \mathrm{~km}$ away. This hypothesis also assumes that no shearing occurs between the inland ice and the ice shelf, and thus requires the increased velocity to follow from a corresponding increase in the flow of ice onto the shelf. However, if the motion of the shelf is the sum of both the rotation and the translation due to spreading and shear at the grounding line, then a centre of rotation near the grounding line is possible. It may be noted that recent field trips in this area have reported a large increase in activity.

If, on the other hand, we assume the flow onto the shelf to be constant and further assume the change in velocity to be a function of position along the flow line, then the implied vertical strain-rates 
are at least an order of magnitude greater than those given by Thomas (1973). There is no other evidence to support this view.

Three possible reasons have been suggested for the observed increase in velocity. First, that it is due to calving in the McDonald Ice Rumples area during 1971-73, though it is not clear that this would result in a sustained increase. The $30 \%$ increase noted by Thomas (1973) in 1969/70 did not continue into 1971 .

A second possibility is an increase in the velocity of the Dalgliesh Ice Stream. The third possibility is suggested by considering the area $50-100 \mathrm{~km}$ to the east of Halley (Thomas, 1973, fig. 2). This area described as consisting of thin ice, open water, and icebergs separates the fast-moving Dalgliesh Ice Stream from the more slowly moving part of the ice shelf on which Halley is situated. During 1981-82 one of the authors travelled to this area and observed that it consisted of heavily crevassed shelf ice. This ice, although considerably lower than the surrounding area, would allow a greater velocity transfer from the Dalgliesh Ice Stream to the Brunt Ice Shelf than would the earlier mixture of thin ice, open water, and icebergs.

\section{CONCLUSION}

These observations, related as they are to a single small area of the ice shelf, raise more questions than they answer, and do not allow us to distinguish between different hypotheses. It is clear, however, that the Brunt Ice Shelf cannot be thought of as being in a "steady state", and that a successful hypothesis has to explain a velocity that is approximately twice that found by Thomas (1973) and sustained for eight years or more.

\section{ACKNOWLEDGEMENTS}

The authors would like to thank the many staff in the Antarctic who made the observations, often in extreme conditions, and numerous colleagues in Cambridge, for suggestions, criticism, and discussion. They would also like to thank R.H. Thomas for several ideas that have been incorporated into the discussion.

\section{REFERENCES}

Ardus, D.A. 1965[a]. Morphology and regime of the Brunt Ice Shelf and the adjacent inland ice 1960-61. British Antarctic Survey. Bulletin, No. 5, p. 13-42.

Ardus, D.A. 1965[b]. Surface deformation, absolute movement, and mass balance of the Brunt Ice Shelf near Halley Bay, 1961. British Antarctic Survey. Bulletin, No. 6, p. 21-41.

Barclay, L.W. 1964. Sledging and surveying. (In Brunt, Sir D., ed. The Royal Society International Geophysical Year Antarctic Expedition. Halley Bay, Coats Lane, Falkland Islands Dependencies, 1955-59. Vol. 4. London, Royal Society, p. 329-38.)

Limbert, D.W.S. 1963. The snow accumulation budget at $\mathrm{Halley}$ Bay in 1959, and associated meteorological factors. British Antarctic Survey. Bulletin, No. 2, p. 73-92.

Limbert, D.W.S. 1964. The absolute and relative movement, and regime of the Brunt Ice Shelf near Halley Bay. British Antarctic Survey. Bulletin, №. 3, p. $1-11$.

Thomas, R.H. 1973. The dynamics of the Brunt Ice Shelf, Coats Land, Antarctica. British Antarctic Survey. Scientific Reports, No. 79.

MS. received 5 March 1984 and in revised form 5 May 1984 